\title{
Optimization of Different Anti Stripping Agents in Construction of Flexible Pavement
}

\author{
Purnima Tripathi ${ }^{1}$, D. S. Ray ${ }^{2}$ \\ ${ }^{1} \mathrm{M}$. tech Scholar, Department of Civil Engineering, BBDU, Lucknow, India. \\ ${ }^{2}$ Prof. and Head of Department of Civil Engineering, BBDNITM, Lucknow, India.
}

\begin{abstract}
The aim of this research project is to improve current practice by investigating different test methods to quantify moisture damage to serve the short- and longterm needs of the agency and industry. This research deals with important concepts of stripping as, bitumen chemistry and rheology, aggregate properties (chemical and mineralogical composition, surface texture, morphology, porosity, etc.), traffic, water properties, construction practices (mixing, placement and in-service drainage) and nature of antistripping additives.

This paper presents the effect of anti-stripping additives in bituminous mixes. As per researches series of laboratory tests have been conducted with varying percentage of these Anti-stripping additives, added Individually and in Combinations, to determine their optimum percentages. This report presents the results of experimental investigations carried out to study the effect of Wetbond-S, Zycotherm and Bitugrip on bitumen and aggregate. Boiling water test and Stripping value test were conducted as screening tests performed on Wetbond-S, Bitugrip and Zycotherm modified bitumen. The current research shows the optimization of different anti- stripping additives to evaluate moisture susceptibilities of bituminous mixes. This paper deals with the review of some previous studies that are done to improve the adhesion between bitumen and aggregate. The stripping value decreases while increasing the percentage of anti- stripping additives to the bitumen. The results indicated that the addition of anti-stripping agents increase moisture resistance of asphalt mixes to some extent. Moreover, it was concluded that mix samples prepared using anti-stripping additive imparted more correlation and greater resistance to water damage.
\end{abstract}

Keywords: Bitumen, Aggregate, Adhesion, Stripping, Wetbond-S, Zycotherm, Bitugrip, Boiling water test, Stripping value test.

\section{INTRODUCTION}

Road sectors are the engines of growth for economy, employment and empowerment. Owing to increases in household income, the demands for personalized vehicles have also increased. In India $95 \%$ of roads are bituminous roads which consists approximately $93-95 \%$ of aggregate and $5-7 \%$ of binder material. Until now conventional bituminous binders were performing satisfactory results but with increase in traffic intensity there is a need of better binder material which can perform better under heavy traffic loads without compromising the performance of bituminous mix. Many mileages of roadway worldwide have been replaced prematurely, due to moisture-induced damage in form of stripping. During Rainy season the natural bitumen become failure and possess serious problem. Due to the movement of vehicular traffic, treatment and strengthening of bitumen appear to be the only solution for keeping the pavement of surfaces serviceable. Loss of adhesion also renders cohesive resistance of the interstitial bitumen useless.

In recent years, stripping has been a serious problem in asphalt paving mixture. The loss of bond between aggregates and asphalt binder that generally begins at the bottom of the HMA layer and progresses upward is understood to be stripping of pavement. It causes functional weakening of pavements leading to costly repairs. It can also cause the premature pavement failures like rutting and raveling on the pavement surface. The most common technique to mitigate moisture damage is the use of additives or modifiers with the asphalt binder or the aggregate. To alleviate or to regulate the deformations due to water damage, various researches were performed resulting in the use of anti-stripping additives. Anti-stripping additives are used to increase physio-chemical bond between the bitumen and aggregate and to improve wetting by lowering the surface tension of the bitumen. Numerous studies indicate that anti-stripping additives can positively affect the binderaggregate bonding characteristics and overall mixture performance by reducing mixtures moisture susceptibility. In India, method of determination of stripping value of road aggregates (IS:6241-1971) is the standard describing the stripping test for the coarse aggregates. The research is done by adding the anti- stripping agents to the bitumen the stripping value test is performed to describe the property of the anti-stripping agents on the bitumen.

\subsection{ADHESION}

One of the fundamental properties for good performances of bituminous pavement is proper adhesion between aggregate and bitumen. The adhesion between mineral aggregates and bitumen is an important criterion which describes the quality of asphalt mixture, asphalt performance and resistance to distress. The lack of bonding can lead to significant asphalt pavement damage. For the evaluation of the adhesion behavior between bitumen and aggregates, used in road construction, many tests have been practiced. The adhesion is influenced by the characteristics of both the bitumen and the aggregate used in the mixture. Adhesion can be generally 
defined as the molecular force of attraction between two bodies of different nature in contact with each other.

\subsection{STRIPPING}

The use of bitumen is reflected in many applications and dates to ancient times. In bituminous mixes, bitumen holds the aggregates forming a mass that supports high stresses. It is crucial that strong and durable interfacial bonds exist under all conditions. Depending on how bitumen interacts with aggregate, stripping may affect this desirable precept. Stripping is the breaking of the adhesion bond between the aggregates and the bituminous binder. In one way or the other water gets in between the binder film and the aggregate surface and because the aggregate surface has higher attraction for water than for bituminous binder then adhesive bond is broken. It is one of the most commonly occurring distresses in asphalt pavements. Surface moisture content is most desirable factor for stripping analysis as most of the bond loss between aggregate and binder starts from pavement surface due to the moisture content from atmosphere and other outer sources.

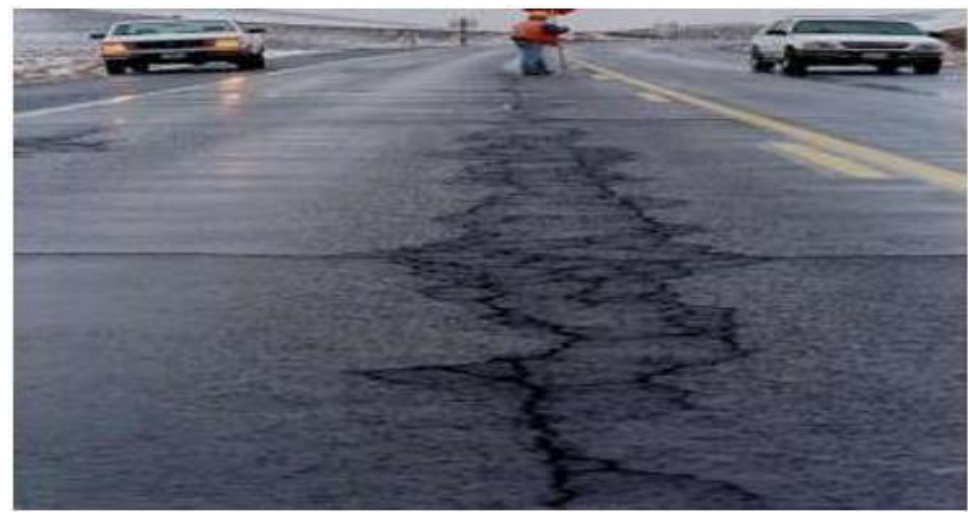

Fig 1: Cracking caused by stripping at the bottom of HMA layer

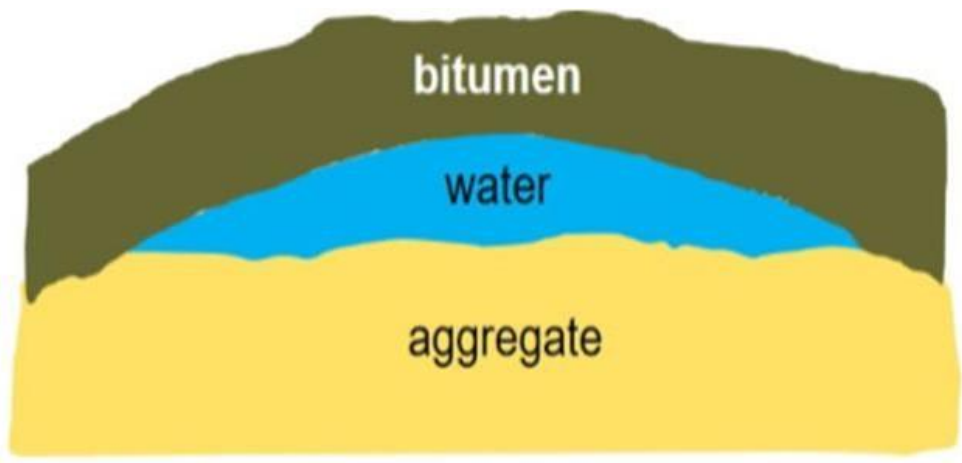

Fig 2: Adhesion failure at the Aggregate-Bitumen interface
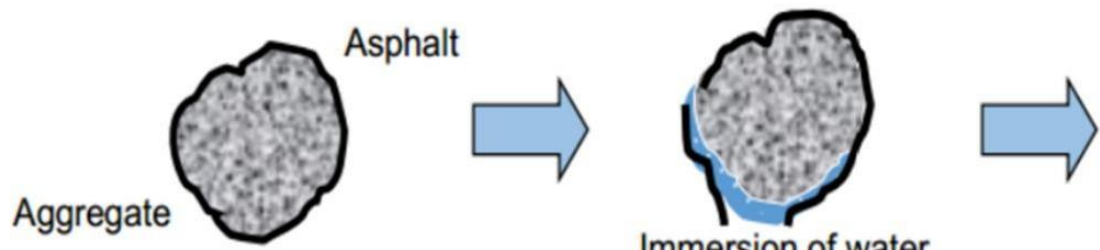

Stripping

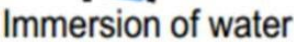

into interface

Fig 3: Conceptual diagram of stripping mechanism

\section{LITERATURE REVIEW}

The following literature review describes important research results regarding use of Wetbond-S, Zycotherm and Bitugrip in bituminous mix in construction of flexible pavement:

Mahmoud Ameri, Sareh Kouchaki (2013) ${ }^{\mathbf{6}}$ The objective of this research study was to evaluate moisture susceptibility of hot mix asphalt (HMA) with and without Zycosoil as a nano-organosilane anti-stripping additive and hydrated lime in the form of slurry. It was also observed that the effects of anti-stripping additives on specimens made by siliceous aggregate are more pronounced than those prepared with limestone aggregates. The use of Zycosoil additive will increase adhesion bond between the aggregates and asphalt binders, and in turn influences the moisture resistance of the mixture to moisture damage.

Dae-Wook Park, Woo-Jin Seo (2017) ${ }^{\mathbf{1}}$ This paper studied that Evaluation of moisture susceptibility of asphalt mixture using liquid anti-stripping agents. The purposes of this study are to comprehensively evaluate the moisture susceptibility of asphalt mixtures modified with several anti-stripping 
additives based on laboratory tests. Boiling water test was conducted as a screening test. The addition of anti-stripping agents significantly improves asphalt mixture stripping resistance before and after stripping occurs, and rutting resistance.

Harpreet Singh, Tanuj Chopra (2017) ${ }^{4}$ In this study, Zycotherm additive is added to neat bitumen and various comparisons were made using conventional test and rheological test on bitumen. Zycotherm gives better chemical bonding for extended moisture resistance and it ensures about $100 \%$ coating of bitumen at low temperature. Hamed Omrani, Ali Reza Ghanizadeh (2017) ${ }^{3}$ The primary objective of this study is exploring the moisture susceptibility of unmodified and SBS-modified hot and warm mix asphalt mixtures. Two different WMA additives including Aspha-min and Sasobit were employed to fabricate WMA specimens. The moisture susceptibility of warm polymer modified asphalt (WPMA) mixes was evaluated. In addition, the effect of different percentages of hydrated lime (from $0 \%$ to $2 \%$ ) and Zycosoil (from $0 \%$ to $0.1 \%$ ) as anti-stripping additives on the moisture susceptibility of the mixtures was explored. The test results showed that increasing moisture content decreases moisture damage resistance. Addition of hydrated lime improves moisture susceptibility. The results also showed that moisture sensitivity was affected significantly by the source of used aggregate.

H. Khani Sanij, P. Afkhamy Meybodi (2018) ${ }^{2}$ The primary goal of these efforts is to improve the durability and load-bearing performance of asphalt mixtures. In this study, glass particles were used, as aggregates in warm mix asphalt (WMA) mixtures. The objective of this study was to consequences the utilization of Zycotherm TM as an antistripping agent have on the mechanical properties and moisture susceptibility of glass-asphalt. Four different amounts of Zycotherm TM were used in WMA mixtures to serve as bitumen modifier and anti-stripping agent. In this study, glass particles were used, as aggregates in warm mix asphalt (WMA) mixtures. Four different amounts of Zycotherm-TM were utilized in WMA mixtures to serve as bitumen modifier and anti-stripping agent.
Kunalkumar Vaghela, Asso. Prof. V.J. Chitaria (2018) ${ }^{\mathbf{5}}$ This study investigates the effects of anti-stripping agent on the microscopic strength of the mineral aggregate contact surface of mixture. The study compared the moisture susceptibility of three variations of bituminous concrete grade 1 mix: (i) Mix without anti-stripping additive (2) Mix with hydrated lime as an anti-stripping additive and (3) Mix with Zycosoil as an anti-stripping additive. The current study resulted in improved bituminous mixtures with the utilization of antistripping additives, especially in the moisture resistance property of the mixture.

Shazi, Prof. D. S. Ray (2018) ${ }^{7}$ This paper aims at the study of potholes on the bituminous road surface and introducing the antistripping material to the bitumen to increase the durability of the road. In this paper, the antistripping material 'Bitugrip' is used to improve the adhesion properties of bitumen and aggregates. The stripping value decreases while increasing the percentage of Bitugrip to the bitumen. Overall, the addition of Bitugrip has a positive influence on the adhesion properties between the aggregates and the bitumen and can be used to increase the durability of roads, thereby reduce the maintenance cost of the roads.

\section{MATERIALS}

To construct a flexible pavement, basically Bitumen and Aggregates are used. Here 3 anti stripping agents i.e. Wetbond-S, Zycotherm and Bitugrip are used to reduce mitigate the problem like stripping, rutting, raveling, potholes, cracking etc and also to reduce maintenance cost and increase service life of pavement. The details of these materials used in this research are mention below:

3.1 BITUMEN: Bitumen is hydrocarbon material, found in gaseous, liquid, semisolid or solid form and is completely soluble in Carbon di-sulphide and in Carbon tetra chloride. It contains $87 \%$ carbon, $11 \%$ hydrogen and $2 \%$ oxygen. Bitumen is a complex organic material and occurs either naturally or may be obtained artificially during the distillation of petroleum. Bituminous materials are very commonly used in highway construction because of their binding and water proofing properties. In this study, VG-30 bitumen grade is used as a base binder.

Table 1: Conventional Properties of Bitumen

\begin{tabular}{|c|c|c|}
\hline S. No. & TESTS OF BITUMEN & BITUMEN USED \\
\hline 1. & PENETRATION TEST $(\mathrm{mm})$ & 56 \\
\hline 2. & SOFTENING POINT TEST $\left({ }^{\circ} \mathrm{C}\right)$ & 50 \\
\hline 3. & DUCTILITY TEST $(\mathrm{cm})$ & 60 \\
\hline
\end{tabular}

3.2 AGGREGATES: Aggregates forms the major portion of pavement structure and they form the prime materials used in pavement construction. Aggregates have to bear stresses occurring due to wheel loads on the pavement and on the surface course they also have to resist wear due to abrasive action of traffic.

Aggregates are inert granular materials like sand, gravel or crushed stone. Gravel aggregates are small rounded stones of different sizes. Aggregates were used local granite rocks of such particle size obtained from KABARAI quarry situated in MAHOBA that are $100 \%$ passed from a $20 \mathrm{~mm}$ sieve and were retained on a $13.2 \mathrm{~mm}$ sieve. The aggregate was washed in distilled water to get rid of all fines dried at $105-110^{\circ} \mathrm{C}$ to constant weight and stored in airtight containers until required to be used. Crushed granite aggregates obtained from nearby quarry was used for the study and they were sufficiently strong, hard, tough, and well-shaped.

3.3 ZYCOTHERM: Zycotherm additive is an odourless nano-organosilane additive used for bituminous mixes. Zycotherm gives better chemical bonding for extended moisture resistance and it ensures about $100 \%$ coating of bitumen at low temperature. In addition, this additive can reduce the production and compaction temperature of asphalt mixtures. 
Table 2: Properties of Zycotherm

\begin{tabular}{|l|l|}
\hline Properties & Results \\
\hline Specific gravity & $0.97 \mathrm{gm} / \mathrm{cm} 3$ \\
\hline Viscosity & $1-5 \mathrm{Pas}$ \\
\hline Flash point & $>80^{\circ} \mathrm{C}$ \\
\hline Colour & Pale yellow \\
\hline Physical state & Liquid \\
\hline Solubility in water & Soluble in water \\
\hline
\end{tabular}

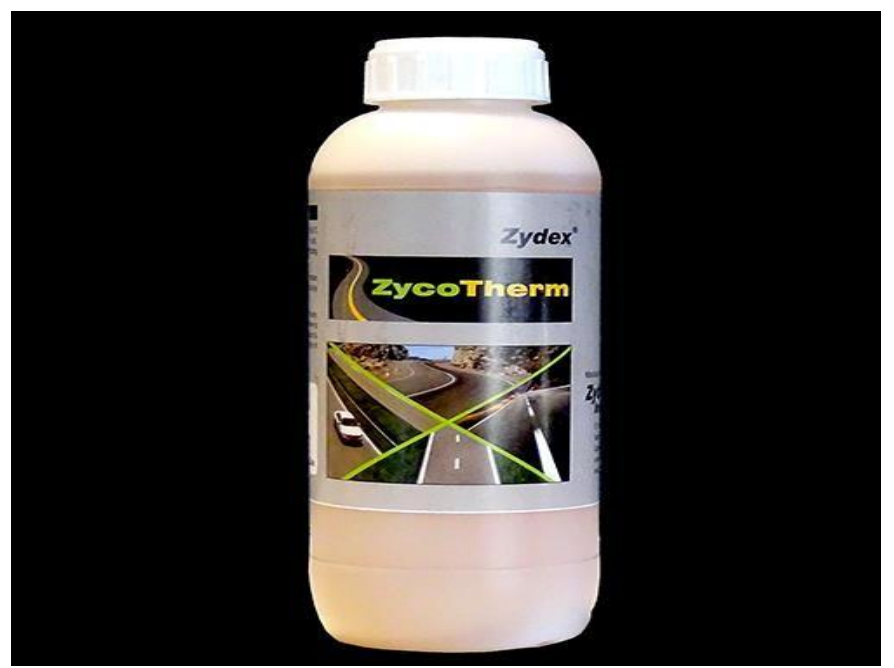

Fig 4 : Zycotherm

3.4 BITUGRIP: Bitugrip is the product of HINCOL (Hindustan Colas Private Limited). Hincol bitugrip is an Amine based anti-stripping agent that changes interfacial surface tension between bitumen and strengthening the bond for long run durability.

aggregate,

Table 3: Properties of Bitugrip

\begin{tabular}{|l|l|}
\hline Properties & Results \\
\hline Density & $1.04 \mathrm{gm} / \mathrm{cm} 3$ \\
\hline Consistency & High viscosity \\
\hline Drying Time $@ 25^{\circ} \mathrm{C}$ & 24 hours \\
\hline Toxicity & Dry film non-toxic \\
\hline
\end{tabular}

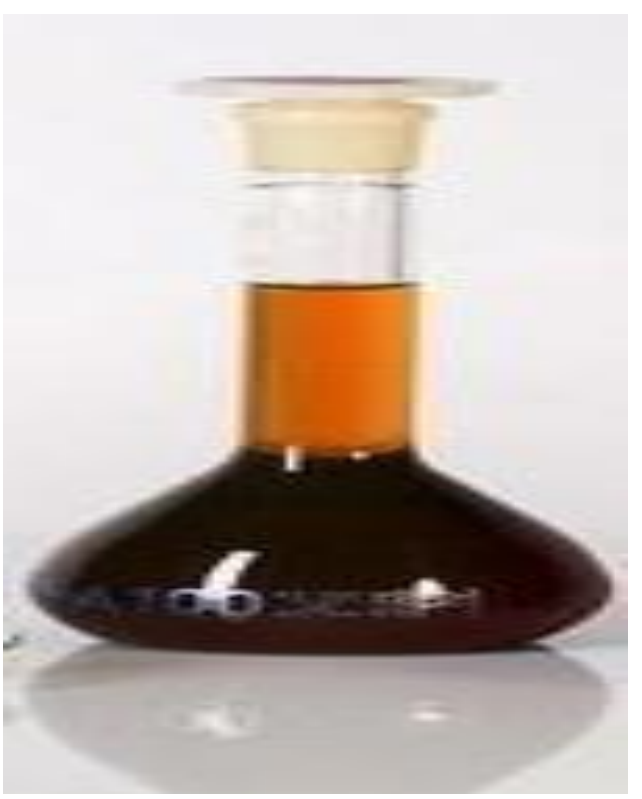

Fig 5: Bitugrip 
3.5 WETBOND-S: "Wetbond-S" is next generation Nanotechnology Silicon based ASA for Asphalt. This product is a low dose and extremely thermal resistive additive for use in Hot-mix and Warm-mix road constructions. This product is especially suitable for aggregates having very high and difficult to manage stripping profile. This product is suitable for production of Refinery-treated non-stripping bitumen, Hot-mix pavement constructions, Warm-mix constructions and for industrial bituminous coatings.

Table 4: Properties of Wetbond-S

\begin{tabular}{|l|l|}
\hline Properties & Results \\
\hline Specific Gravity & $0.86-0.95$ \\
\hline Amine Value & $>200$ \\
\hline Active Nitrogen & $>7$ \\
\hline Water Content & $<1 \%$ \\
\hline Active content & $100 \%$ \\
\hline Shelf Life & 4 Years from the date of production in sealed containers. \\
\hline Colour & Brownish clear liquid. \\
\hline Compatibility & All grades of Road and Industrial Bitumen's. \\
\hline
\end{tabular}

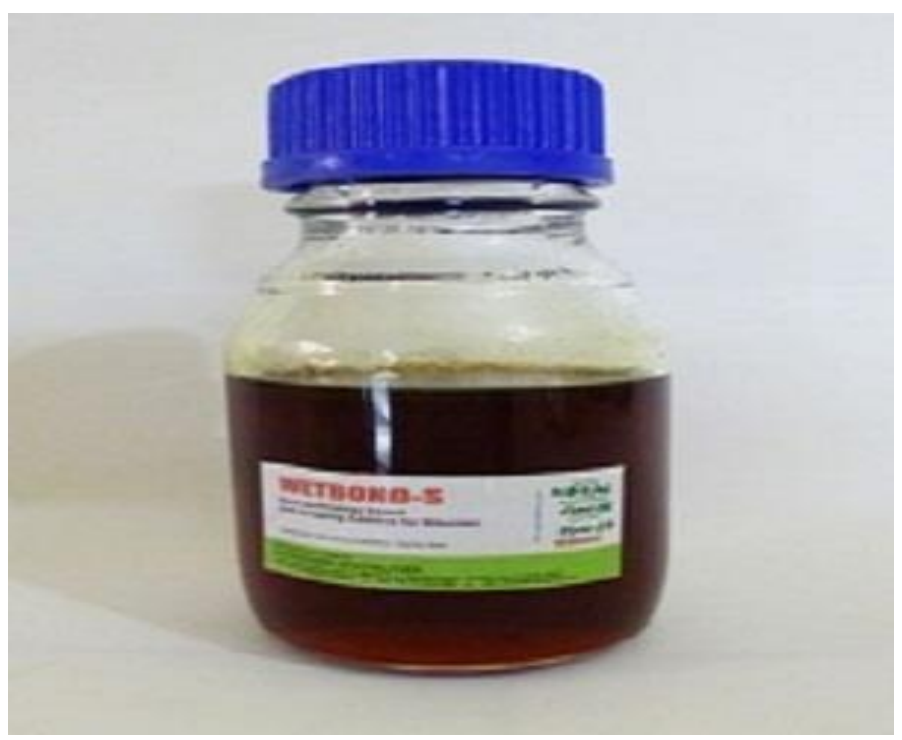

Fig 6: Wetbond-S

Advantages of Antistripping Agents:

- Enhance the service life of the pavement

- Excellent adhesion promoter onto all type of aggregates

- Slow down age hardening of bitumen

- Low dosage required

- Stable at high process temperature of hot mix temperature.

\section{EXPERIMENTAL INVESTIGATION}

In the first, Boiling water test and stripping value test were done without adding any ASA and calculate the stripping value. After that these three ASA were used with various percentages like Wetbond-S in $\mathbf{0 . 0 5}, \mathbf{0 . 0 7}, \mathbf{0 . 1 0} \& \mathbf{0 . 1 5 \%}$, Zycotherm in 0.05, 0.075, 0.10 \& $0.15 \%$ and Bitugrip in $0.5,0.75,1.0 \& 1.5 \%$ by wt. of bitumen to check the optimum dosages of all these ASA. As Wetbond-S showed min stripping at $\mathbf{0 . 1 0 \%}$, Zycotherm at $\mathbf{0 . 0 7 5 \%}$ and Bitugrip at $\mathbf{1 . 0 \%}$. After getting optimum dosage, combination was made to obtain minimum value of stripping.

Table 5: Optimum Values of ASA in Boiling Water Test (adding individually)

\begin{tabular}{|c|c|c|c|}
\hline S. No. & $\begin{array}{c}\text { Name of Anti- Stripping } \\
\text { Agent }\end{array}$ & $\begin{array}{c}\text { Optimum Quantity of Anti- } \\
\text { Stripping Agent (\%) }\end{array}$ & Stripping Value (\%) \\
\hline 1. & No ASA & 0 & 10 \\
\hline 2. & Wetbond-S & 0.10 & 1.43 \\
\hline 3. & Zycotherm & 0.075 & 1.44 \\
\hline 4. & Bitugrip & 1.0 & 1.95 \\
\hline
\end{tabular}


Case 1: Boiling water test is performed without adding any ASA in bituminous mix-

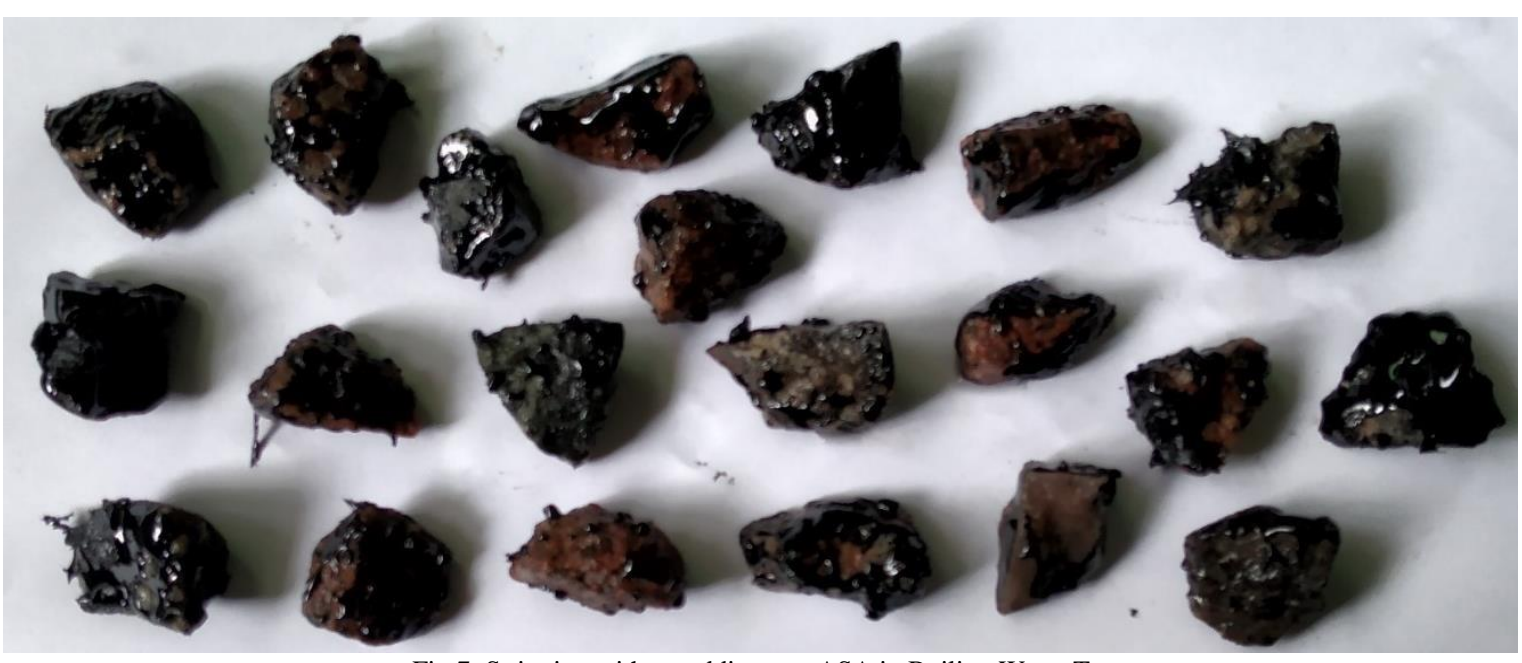

Fig 7: Stripping without adding any ASA in Boiling Water Test

Case 2: When $0.10 \%$ Wetbond-S is added in the mix in boiling water test

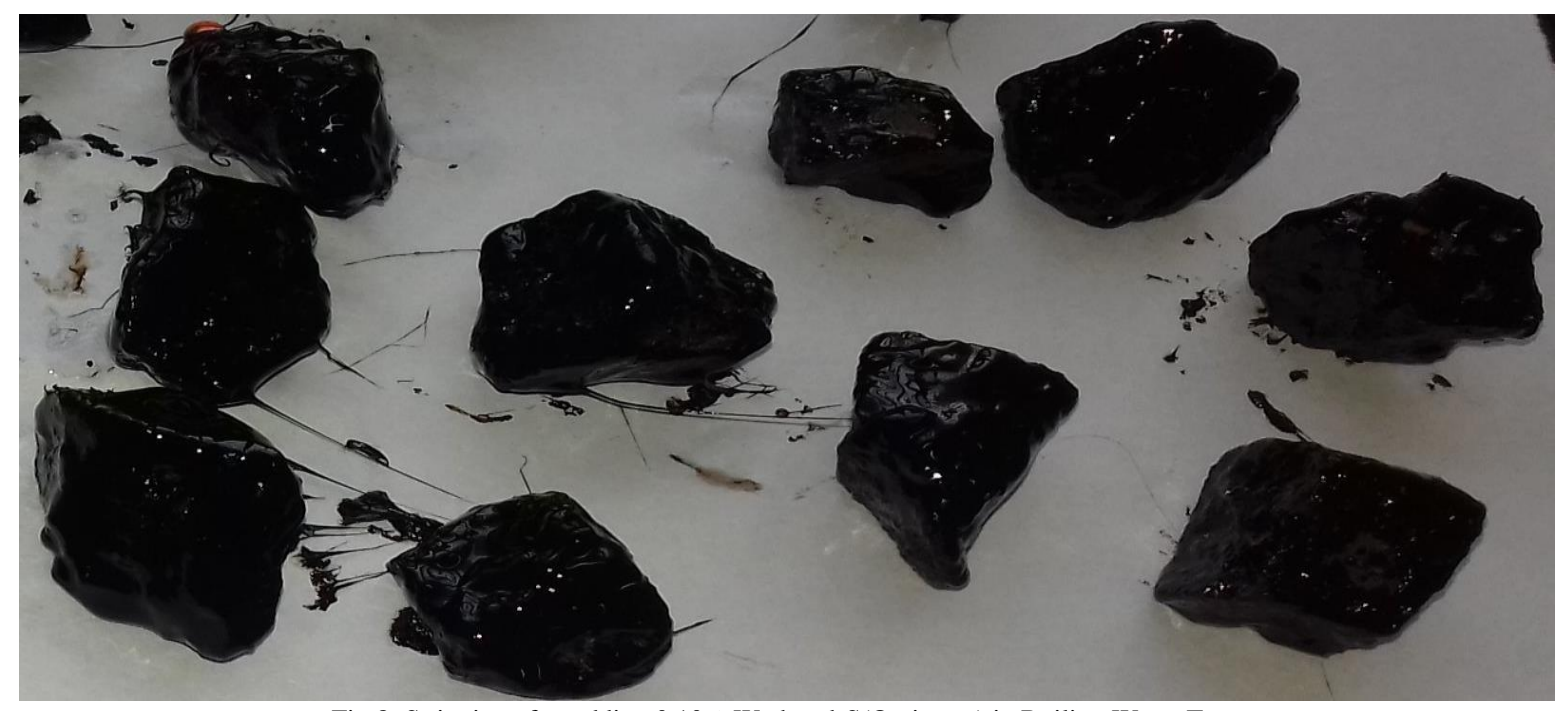

Fig 8: Stripping after adding 0.10\% Wetbond-S(Optimum) in Boiling Water Test

Case 3: When $0.075 \%$ Zycotherm is added in mix in boiling water test

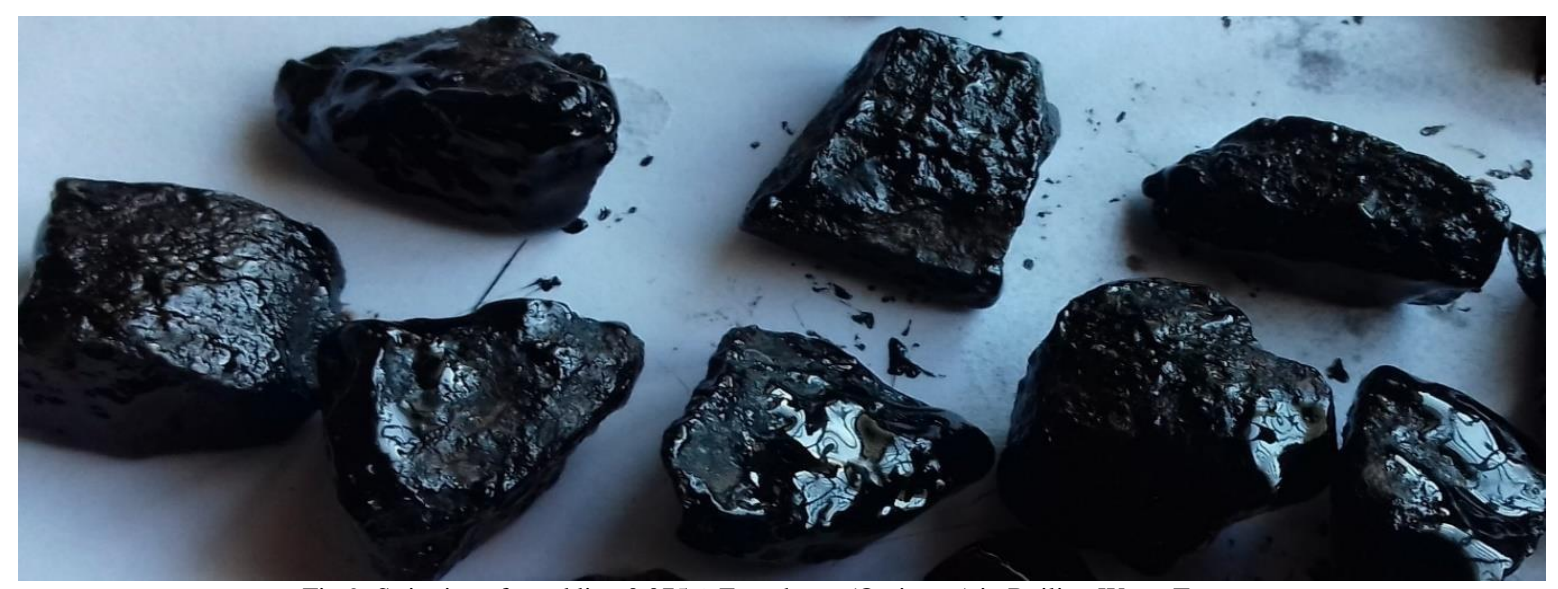

Fig 9: Stripping after adding 0.075\% Zycotherm (Optimum) in Boiling Water Test 
Case 4: When 1\% Bitugrip is added in mix in boiling water test

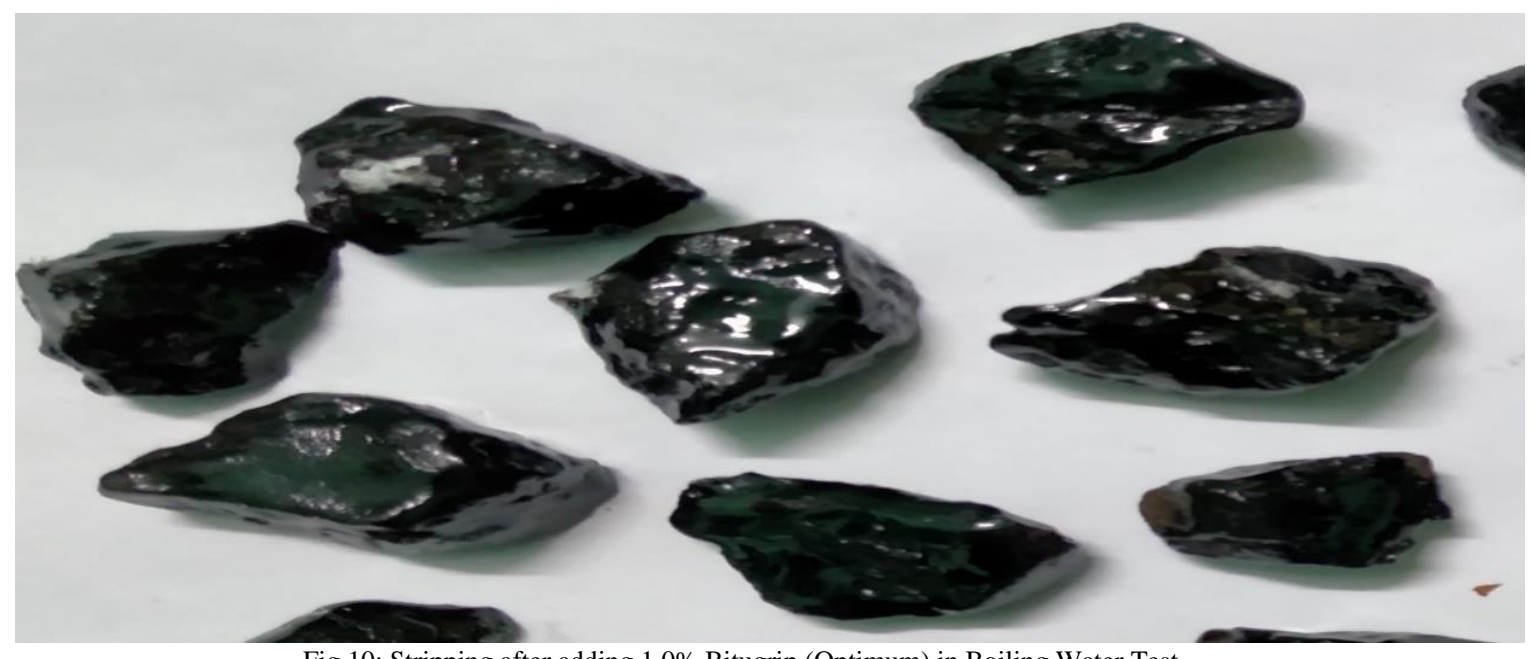

Fig 10: Stripping after adding 1.0\% Bitugrip (Optimum) in Boiling Water Test

Table 6: Optimum Values of ASA in Stripping Value Test (adding individually)

\begin{tabular}{|c|c|c|c|}
\hline S. No. & $\begin{array}{c}\text { Name of Anti- Stripping } \\
\text { Agent }\end{array}$ & $\begin{array}{c}\text { Optimum Quantity of Anti- } \\
\text { Stripping Agent (\%) }\end{array}$ & Stripping Value (\%) \\
\hline 1. & No ASA & 0 & 8.1 \\
\hline 2. & Wetbond-S & 0.10 & 1.43 \\
\hline 3. & Zycotherm & 0.075 & 0.94 \\
\hline 4. & Bitugrip & 1.0 & 1.95 \\
\hline
\end{tabular}

Case 5. Stripping Value Test performed without adding any ASA-

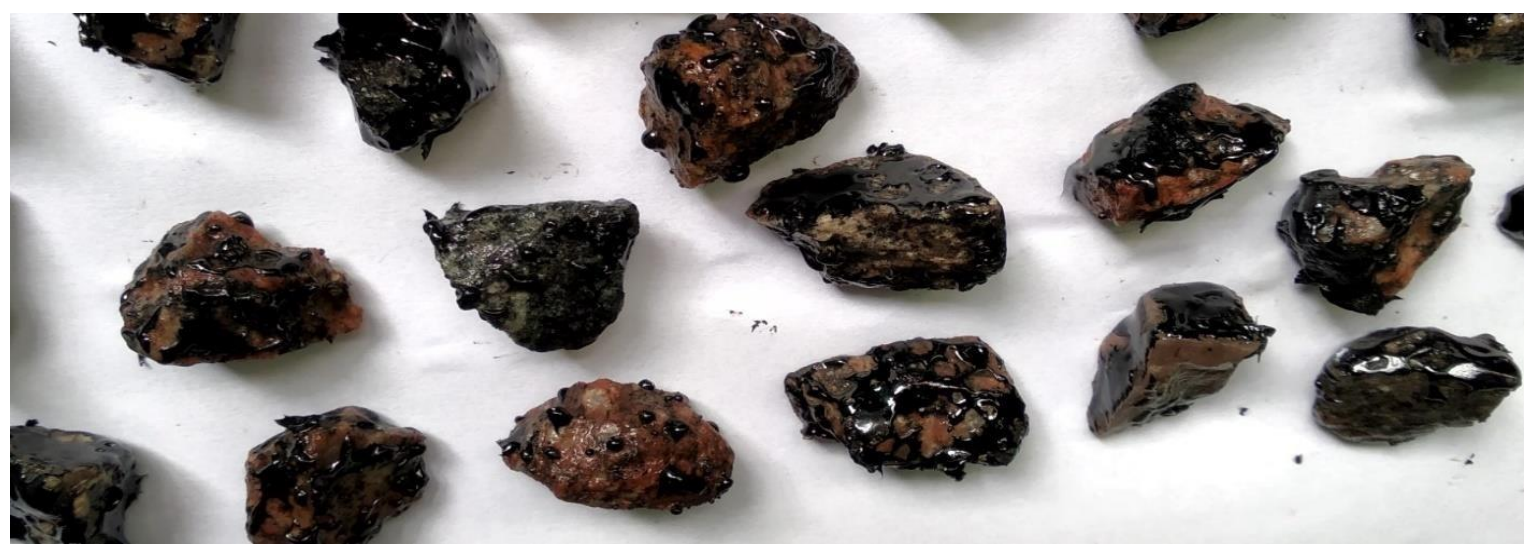

Fig 11: Stripping without adding any ASA in Stripping Value Test

Case 6: When $0.10 \%$ Wetbond-S added to the mix in stripping value test-

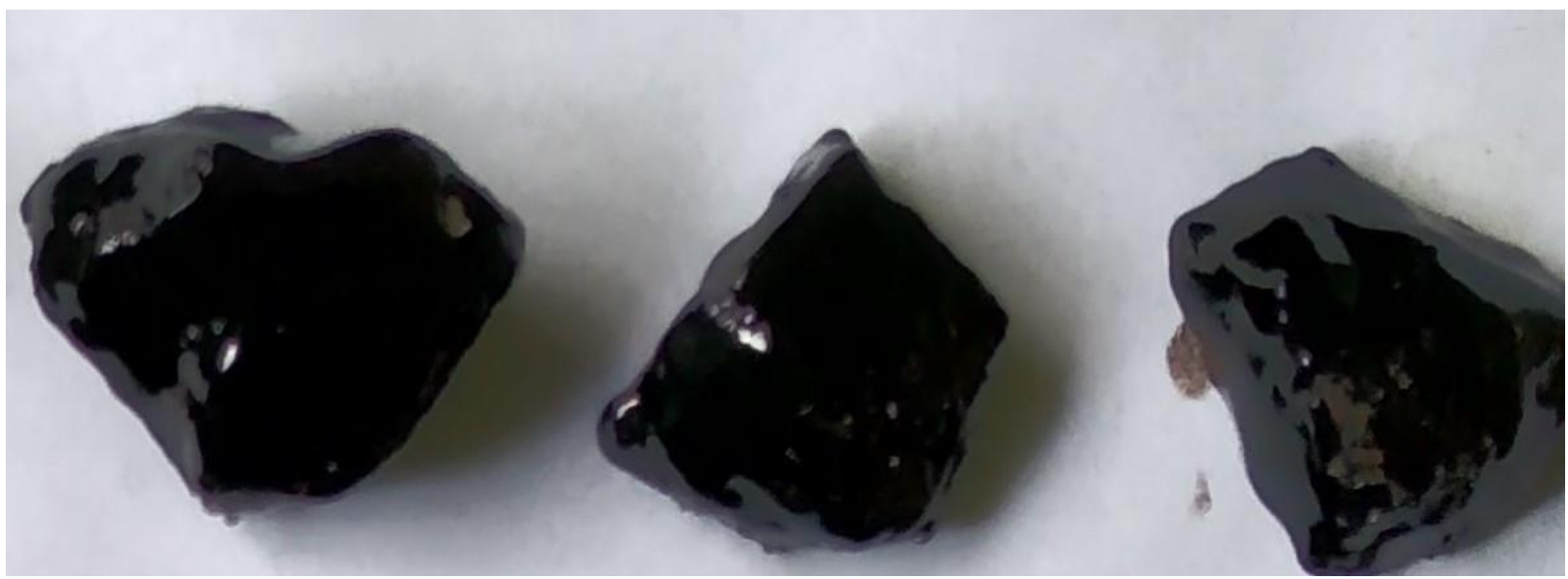

Fig 12: Stripping after adding 0.10\% Wetbond-S(Optimum) in Stripping Value Test 
Case 7: when $0.075 \%$ Zycotherm is added to mix in stripping value test-

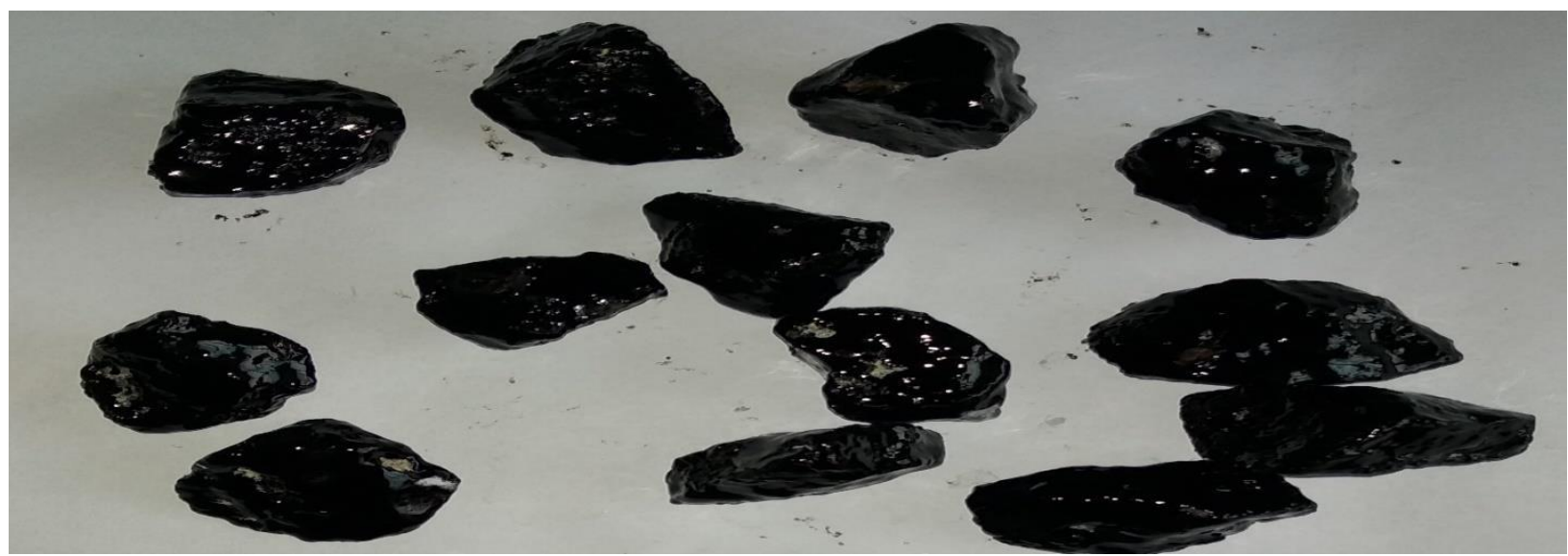

Fig 13: Stripping after adding 0.075\% Zycotherm (Optimum) in Stripping Value Test

Case 8: When $1 \%$ Bitugrip added in mix in stripping value test

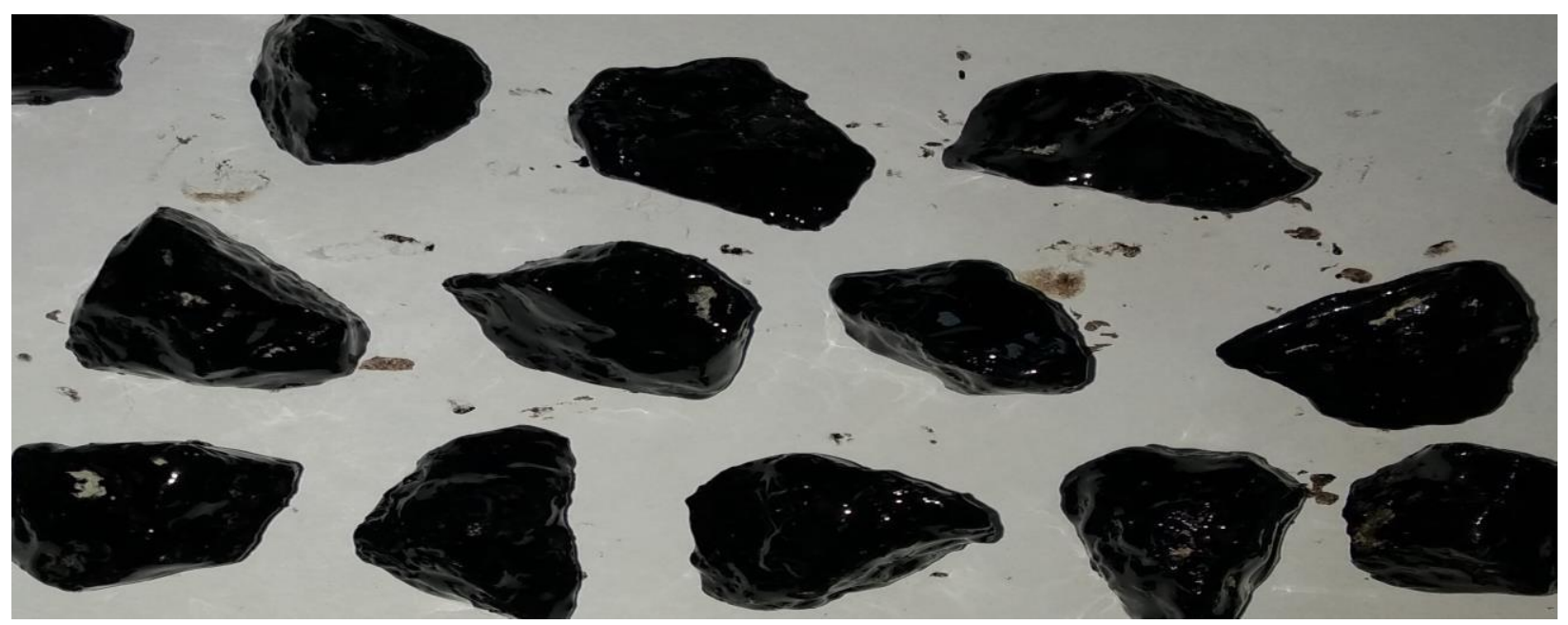

Fig 14: Stripping after adding 1.0\% Bitugrip (Optimum) in Stripping Value Test

- As Wetbond-S \& Zycotherm had given better result compared to Bitugrip so here Bitugrip was neglected.

Table 7: Combinations of ASA with optimum values in Boiling Water Test

\begin{tabular}{|c|c|c|}
\hline S.No. & Combination of ASA & Stripping Value \\
\hline 1. & Wetbond-S + Zycotherm & 1.40 \\
\hline 2. & Wetbond-S + Bitugrip & 1.42 \\
\hline 3. & Wetbond-S + Zycotherm + Bitugrip & 1.40 \\
\hline
\end{tabular}

Case 9: When Wetbond-S+Zycotherm is added in mix in boiling water test 


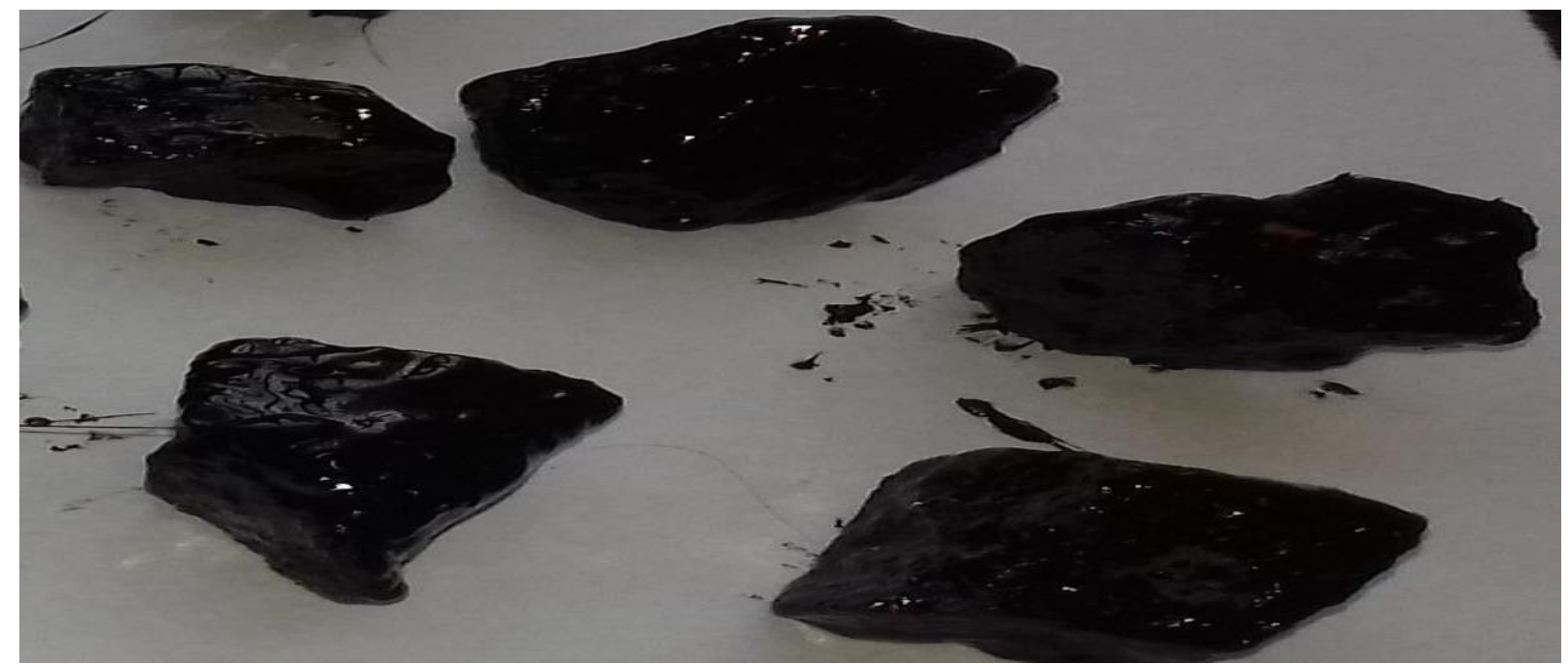

Fig 15: Stripping after adding optimum dose of Wetbond-S+ Zycotherm in Boiling Water Test

Table 8: Combinations of ASA with optimum values in Stripping Value Test

\begin{tabular}{|c|c|c|}
\hline S.No. & Combination of ASA & Stripping Value \\
\hline 1. & Wetbond-S+Zycotherm & 1.38 \\
\hline 2. & Wetbond-S+Bitugrip & 1.41 \\
\hline 3. & Wetbond-S+Zycotherm+Bitugrip & 1.375 \\
\hline
\end{tabular}

Case 10: When Wetbond-S+Zycotherm is added in bituminous mix in stripping value test

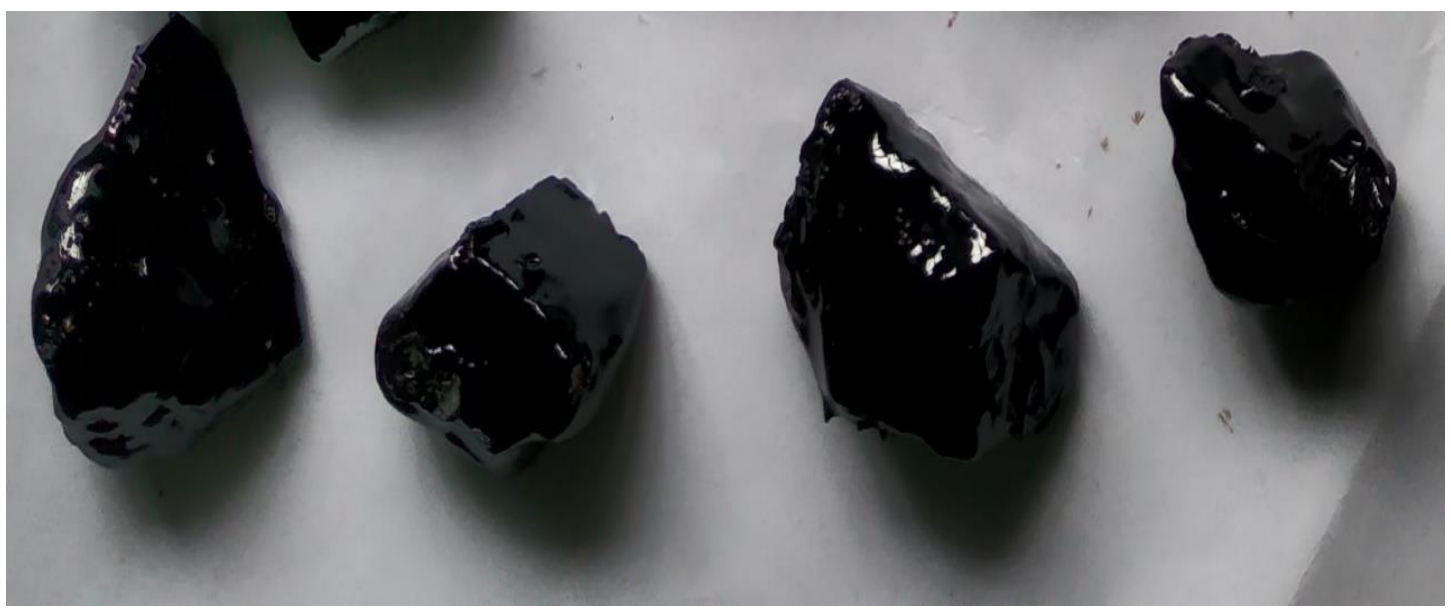

Fig 16: Stripping after adding optimum dose of Wetbond-S+ Zycotherm in Stripping Value Test

\section{RESULT ANALYSIS AND DISCUSSION}

Table 9: ANALYSIS OF MAINTENANCE COST IN CASE OF BOILING WATER TEST

\begin{tabular}{|c|c|c|c|c|c|c|c|c|c|c|c|c|c|}
\hline $\begin{array}{l}\text { S. } \\
\text { No. }\end{array}$ & $\begin{array}{l}\text { Name } \\
\text { of } \\
\text { ASA }\end{array}$ & $\begin{array}{c}\text { ASA } \\
\text { additio } \\
n \\
\text { Optimu } \\
\text { m }(\%)\end{array}$ & $\begin{array}{l}\text { Strippi } \\
\text { ng } \\
\text { Value } \\
(\%)\end{array}$ & $\begin{array}{c}\text { Damag } \\
\text { ed } \\
\text { Area } \\
\text { (sq. } \\
\text { m.) }\end{array}$ & $\begin{array}{l}\text { Paveme } \\
\text { nt } \\
\text { Thickne } \\
\text { ss } \\
(40 \mathrm{~mm})\end{array}$ & $\begin{array}{c}\text { Damag } \\
\text { ed } \\
\text { Quantit } \\
\text { y } \\
\text { (cum) }\end{array}$ & $\begin{array}{l}\text { Rate } \\
\text { of } \\
\text { BC } \\
\text { per } \\
\text { cum }\end{array}$ & $\begin{array}{l}\text { Amount } \\
\text { of } \\
\text { maintena } \\
\text { nce (Rs.) }\end{array}$ & $\begin{array}{c}\text { Quanti } \\
\text { ty of } \\
\text { Bitum } \\
\text { en @ } \\
5.4 \% \\
\text { wt. of } \\
\text { mix }\end{array}$ & $\begin{array}{l}\text { Quanti } \\
\text { ty of } \\
\text { ASA } \\
(\mathrm{Kg})\end{array}$ & $\begin{array}{c}\text { Rate } \\
\text { of } \\
\text { AS } \\
\text { A } \\
\text { Rs. } \\
\text { Per } \\
\text { kg }\end{array}$ & $\begin{array}{r}\text { Cost of } \\
\text { ASA } \\
\text { (Rs.) }\end{array}$ & $\begin{array}{l}\text { Maintena } \\
\text { nce Cost } \\
\text { (Rs.) }\end{array}$ \\
\hline 1 & $\begin{array}{c}\text { No } \\
\text { Agent }\end{array}$ & 0 & 10 & 700 & 0.04 & 28.00 & 9965 & 279020 & 3.56 & 0 & 0 & 0 & 279020 \\
\hline 2 & $\begin{array}{c}\text { Wetbond } \\
-\mathrm{S}\end{array}$ & 0.1 & 1.43 & 100.1 & 0.04 & 4.00 & 9965 & $\begin{array}{c}39899.8 \\
6 \\
\end{array}$ & 0.51 & 50.94 & 765 & $\begin{array}{c}38969.8 \\
2 \\
\end{array}$ & 39899.86 \\
\hline 3 & $\begin{array}{c}\text { Zycother } \\
\mathrm{m}\end{array}$ & 0.075 & 1.44 & 100.8 & 0.04 & 4.03 & 9965 & $\begin{array}{c}40178.8 \\
8\end{array}$ & 0.51 & 38.47 & $\begin{array}{c}135 \\
0 \\
\end{array}$ & $\begin{array}{c}51938.3 \\
9\end{array}$ & 40178.88 \\
\hline
\end{tabular}




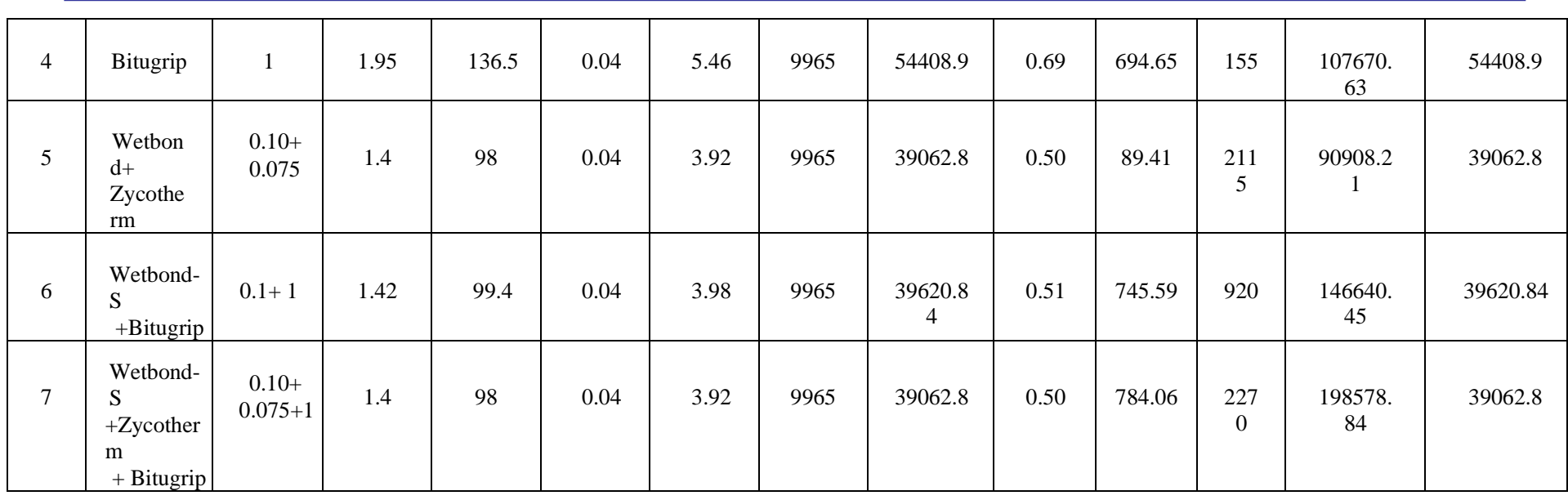

\section{MAINTENANCE COST OF OPTIMUM PERCENTAGES OF COMBINATION OF ADDITIVES}

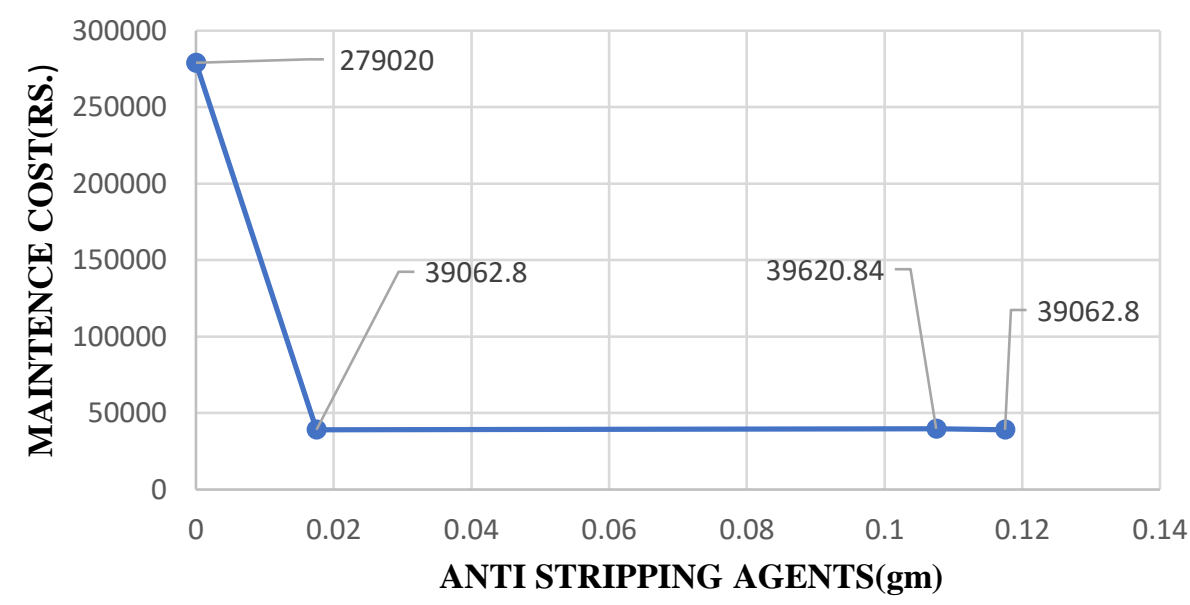

Fig 17: Maintenance Cost v/s Optimum Dose of ASA\% adding in combination in Boiling Water Test

Table 10: ANALYSIS OF MAINTENANCE COST IN CASE OF STRIPPING VALUE TEST

\begin{tabular}{|c|c|c|c|c|c|c|c|c|c|c|c|c|c|}
\hline $\begin{array}{l}\text { S.No } \\
\text {. }\end{array}$ & $\begin{array}{l}\text { Name } \\
\text { of } \\
\text { ASA }\end{array}$ & $\begin{array}{c}\text { ASA } \\
\text { additio } \\
\text { n } \\
\text { Optimu } \\
\text { m (\%) }\end{array}$ & $\begin{array}{l}\text { Strippi } \\
\text { ng } \\
\text { Value( } \\
\%)\end{array}$ & $\begin{array}{c}\text { Damag } \\
\text { ed Area } \\
\text { (sq.m.) }\end{array}$ & $\begin{array}{l}\text { Paveme } \\
\text { nt } \\
\text { Thickne } \\
\text { ss } \\
(40 \mathrm{~mm})\end{array}$ & $\begin{array}{c}\text { Damag } \\
\text { ed } \\
\text { Quantit } \\
y \\
\text { (cum) }\end{array}$ & $\begin{array}{l}\text { Rate } \\
\text { of } \\
\text { BC } \\
\text { per } \\
\text { cum }\end{array}$ & $\begin{array}{l}\text { Amount } \\
\text { of } \\
\text { maintena } \\
\text { nce (Rs.) }\end{array}$ & $\begin{array}{c}\text { Quanti } \\
\text { ty of } \\
\text { Bitum } \\
\text { en @ } \\
5.4 \% \\
\text { wt. of } \\
\text { mix }\end{array}$ & $\begin{array}{l}\text { Quanti } \\
\text { ty of } \\
\text { ASA } \\
(\mathrm{Kg})\end{array}$ & $\begin{array}{c}\text { Rate } \\
\text { of } \\
\text { ASA } \\
\text { Rs. } \\
\text { Per } \\
\text { kg } \\
\end{array}$ & $\begin{array}{l}\text { Cost of } \\
\text { ASA } \\
\text { (Rs.) }\end{array}$ & $\begin{array}{l}\text { Maintena } \\
\text { nce Cost } \\
\text { (Rs.) }\end{array}$ \\
\hline 1 & No Agent & 0 & 8.1 & 567 & $\begin{array}{c}0.0 \\
4 \\
\end{array}$ & 22.68 & 9965 & $\begin{array}{c}226006 \\
.2 \\
\end{array}$ & 2.89 & 0 & 0 & 0 & $\begin{array}{c}226006 \\
.2 \\
\end{array}$ \\
\hline 3 & Zycotherm & 0.075 & 0.96 & 67.2 & $\begin{array}{c}0.0 \\
4\end{array}$ & 2.69 & 9965 & $\begin{array}{c}26785 . \\
92\end{array}$ & 0.34 & 25.65 & $\begin{array}{c}135 \\
0 \\
\end{array}$ & $\begin{array}{c}34625.5 \\
9 \\
\end{array}$ & $\begin{array}{c}26785 . \\
92\end{array}$ \\
\hline 4 & Bitugrip & 1 & 1.95 & 136.5 & $\begin{array}{c}0.0 \\
4 \\
\end{array}$ & 5.46 & 9965 & $\begin{array}{c}54408 . \\
9 \\
\end{array}$ & 0.69 & 694.65 & 155 & $\begin{array}{c}107670 . \\
63 \\
\end{array}$ & $\begin{array}{c}54408 . \\
9 \\
\end{array}$ \\
\hline 5 & $\begin{array}{l}\text { Wetbon } \\
\text { d+ } \\
\text { Zycothe } \\
\text { rm }\end{array}$ & $\begin{array}{l}0.10+ \\
0.075\end{array}$ & 1.42 & 99.4 & $\begin{array}{c}0.0 \\
4\end{array}$ & 3.98 & 9965 & $\begin{array}{c}39620 . \\
84\end{array}$ & 0.51 & 76.59 & $\begin{array}{c}211 \\
5\end{array}$ & $\begin{array}{c}73595.4 \\
1\end{array}$ & $\begin{array}{c}39620 . \\
84\end{array}$ \\
\hline
\end{tabular}




\begin{tabular}{|c|c|c|c|c|c|c|c|c|c|c|c|c|c|}
\hline 6 & $\begin{array}{c}\text { Zycother } \\
\text { m+ } \\
\text { Bitugrip }\end{array}$ & 0.075 & 1.44 & 100.8 & $\begin{array}{c}0.0 \\
4\end{array}$ & 4.03 & 9965 & $\begin{array}{c}40178 . \\
88\end{array}$ & 0.51 & 702.30 & $\begin{array}{c}150 \\
5\end{array}$ & $\begin{array}{c}142296 . \\
22\end{array}$ & $\begin{array}{c}40178 . \\
88\end{array}$ \\
\hline 7 & $\begin{array}{l}\text { Wetbond-S } \\
+ \text { Bitugrip }\end{array}$ & $\begin{array}{c}0.075+ \\
1 \\
\end{array}$ & 1.41 & 98.7 & $\begin{array}{c}0.0 \\
4 \\
\end{array}$ & 3.95 & 9965 & $\begin{array}{c}39341 . \\
82 \\
\end{array}$ & 0.50 & 745.59 & 920 & $\begin{array}{c}146640 . \\
45\end{array}$ & $\begin{array}{c}39341 . \\
82\end{array}$ \\
\hline 8 & $\begin{array}{c}\text { Wetbond-S } \\
+ \text { Zycother } \\
\text { m+ } \\
\text { Bitugrip }\end{array}$ & $\begin{array}{c}0.10+ \\
0.075+1\end{array}$ & $\begin{array}{c}1.37 \\
5\end{array}$ & 96.25 & $\begin{array}{c}0.0 \\
4\end{array}$ & 3.85 & 9965 & $\begin{array}{c}38365 . \\
25\end{array}$ & 0.49 & 771.24 & $\begin{array}{c}227 \\
0\end{array}$ & $\begin{array}{c}181266 . \\
04\end{array}$ & $\begin{array}{c}38365 . \\
25\end{array}$ \\
\hline
\end{tabular}

\section{MAINTENANCE COST OF OPTIMUM PERCENTAGES OF COMBINATION OF ADDITIVES}

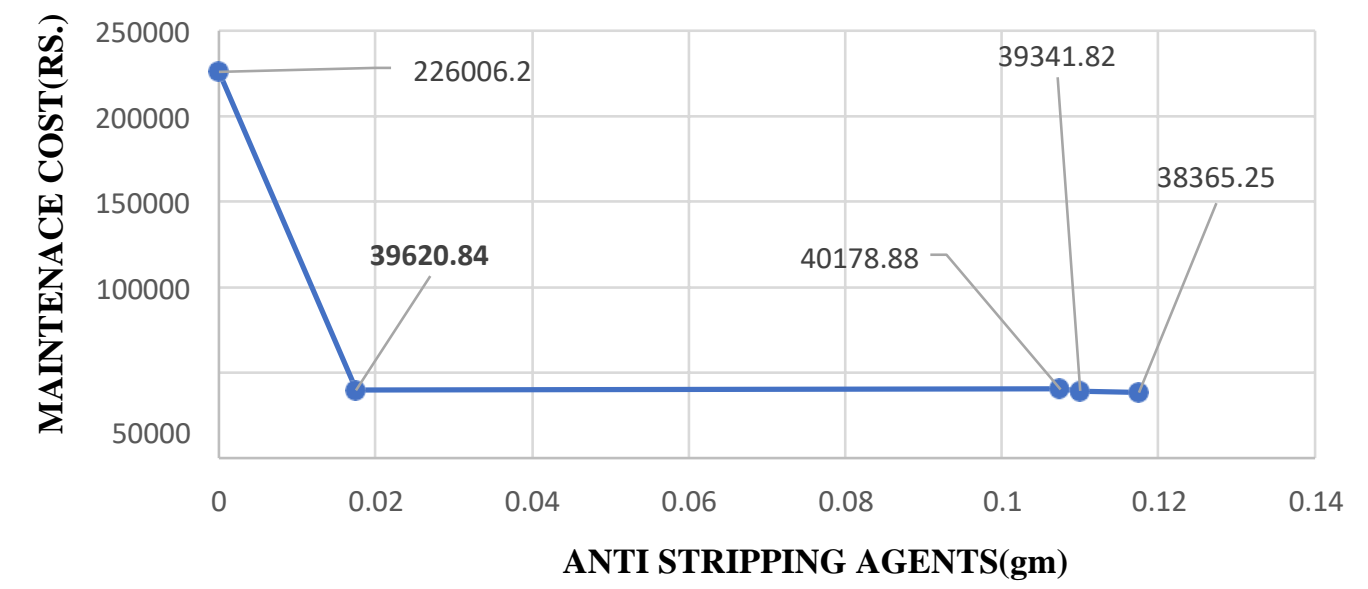

Fig 18: Maintenance Cost v/s Optimum Dose of ASA\% adding in combination in Stripping Value Test

\section{CONCLUSION}

Following conclusions are derived based on laboratory investigations keeping in mind all aspect procedures of codal practice:

- ASAs (Wetbond-S, Zycotherm \& Bitugrip) are chemical admixtures containing active functional groups that improves the adhesion of the bitumen film on the surface of aggregate.

- It has been observed that after addition of ASAs (Wetbond-S, Zycotherm \& Bitugrip), the stripping of Bituminous Mixes reduced.

- Wetbond-S is the most effective in decreasing the stripping value of mixes in case of Boiling Water Test while in same way, Zycotherm is the most effective in case of Stripping Value test.

- After analyzing all the data that is collected or generated, it is found that is (Wetbond-S+ Zycotherm) is the best combination of ASAs for anti-stripping and most economical as compared to individual ASAs used.

- After adding combination of Wetbond-S \& Zycotherm to bituminous mix, max. saving in Boiling Water Test and Stripping Value Test is $86 \%$ \& $82.5 \%$ resp. considering all aspect. Thus, Due to the saving in maintenance cost, less quantity of material will be applicable so that, huge amount of money can be saved.

- As these additives are Silane based additives, minimize the moisture damage as a coating of bitumen is formed around the aggregate.

- When ASAs are mixed with the bituminous binder, lower the surface tension of the bitumen.

- As the ASAs are of low cost, therefore, it is expected to reduce the life cycle cost of the bituminous pavements.

- Using ASAs, durability of road increases as proved in the study.

\section{FUTURE SCOPE}

Based on present work and findings, it is felt that further work should be pursued in the following area:

- The evaluation methods consider mainly moisture sensitivity as the main factor due to which stripping occurs.

- Damage may occur in base course. Evaluation should be carried out considering base course damage.

- Further investigation should be carried out different grades of bitumen.

- No mechanism has been developed yet to determine stripping value, observations are done visually. 
- In laboratory, distilled water is used in experimentation which is neutral with $\mathrm{pH} \mathrm{7,} \mathrm{but}$ there is a large variation in $\mathrm{pH}$ value of water in the field.

\section{REFERENCES}

[1] Dae-Wook Park, Woo-Jin Seo(2017), "Evaluation of moisture susceptibility of asphalt mixture using liquid anti-stripping agents". Construction and Building Materials 144 (2017) 399-405. Mar, 2017.

[2] H. Khani Sanij, P. Afkhamy Meybodi (2018), "Evaluation of performance and moisture sensitivity of glass-containing warm mix asphalt modified with zycotherm TM as an anti-stripping additive". Construction and Building Materials 197 (2019) 185194. Nov, 2018

[3] Hamed Omrani, Ali Reza Ghanizadeh (2017), "Effect of SBS Polymer and Anti-Stripping Agents on the Moisture Susceptibility of Hot and Warm Mix Asphalt Mixtures" Civil Engineering Journal Vol. 3, No. 10, October, 2017.

[4] Harpreet Singh, Tanuj Chopra (2017), "Effect of Zycotherm Performance Of Neat Bitumen And Bituminous Concrete mixes". IJCIET, Volume 8, Issue 8, August 2017

[5] Kunal kumar Vaghela, Asso. Prof. V.J. Chitaria (2018), "Evaluation of Organosilane Based Asphalt Additive for Flexible Pavement”. (IRJET) Volume: 05 Issue: 02 |Feb- 2018.

[6] Mahmoud Ameri, Sareh Kouchaki(2013) "Laboratory evaluation of the effect of nano-organosilane anti-stripping additive on the moisture susceptibility of HMA mixtures under freeze-thaw cycles". Construction and Building Materials 48 (2013) 10091016. July,2013.

[7] Shazi, Prof. D. S. Ray (2018), "Study and Evaluation of Disintegration of Pavement Surface”. IJSRD Vol. 6, Issue 03, 2018.

[8] IS:1203. (1978). Methods for testing tar and bituminous materials; determination of penetration. Bureau of Indian Standards, India.

[9] IS:1205. (1978). Methods for testing tar and bituminous materials; determination of softening point. Bureau of Indian Standards, India.

[10] IS:1208. (1978). Methods for testing tar and bituminous materials; determination of ductility. Bureau of Indian Standards, India.

[11] IS:6241. (1971). Determination of stripping value of aggregates. Bureau of Indian Standards, India.

[12] Maupin, G.W. (2004), "Quantitative Determination of Asphalt Antistripping Additive," Final Report VTRC 05-R3, Virginia Transportation Research Council, Charlottesville, VA. 